ELORE (ISSN 1456-3010), vol. $16-2 / 2009$.

Julkaisija: Suomen Kansantietouden Tutkijain Seura ry.

[http://www.elore.fi/arkisto/2_09/kirjallisuus_salmi-niklander_2_09.pdf]

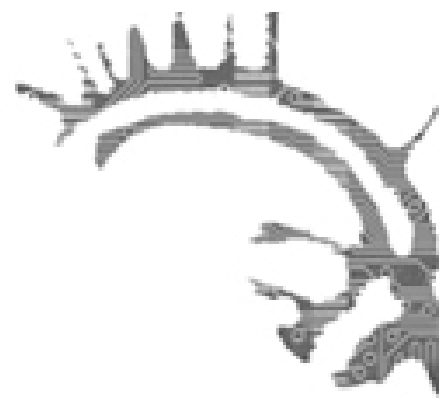

\title{
KiRJA-ARVIO:
}

\section{KEIJUJEN UUSI ELÄMÄ LEHTIEN PALSTOILLA}

Sumpter, Caroline 2008: The Victorian Press and the Fairy Tale. Basingstoke: Palgrave Macmillan. 254 sivua.

\section{$\underline{\text { Kirsti Salmi-Niklander }}$}

Satujen tutkimus on viime vuosina nostattanut kuumia tunteita folkloristien piirissä. Ruth B. Bottigheimer on sohaissut muurahaispesää tuoreilla tutkimuksillaan (Bottigheimer 2002; 2009), joissa hän kyseenalaistaa ihmesatujen suullisen alkuperän ja jäljittää niiden taustoja 1500-1700-luvun kirjallisiin lähteisiin. Satututkimusdebatti on jo alkanut kärjistyä tietynlaiseksi uskonsodaksi "folkloristien/oralistien" ja "antifolkloristien" välillä, vaikka käsitykseni mukaan Ruth Bottigheimer ja hänen samanhenkiset kollegansa eivät millään tavalla kyseenalaista suullisen perinteen olemassaoloa. Satututkimusdebattia jatketaan ensi kesänä (17.-21.8.2010) kirjahistorian SHARPkonferenssissa Helsingissä (ks. Salmi-Niklander 2009). Ruth B. Bottigheimerin keynoteluentoon liittyen järjestetään satututkimuspaneeli, johon osallistuvat myös professori Satu Apo ja tutkija Caroline Sumpter Queen's yliopistosta Belfastista. Paneeli tarjoaa erinomaisen mahdollisuuden satututkimuskeskustelun jatkamiseen positiivisessa, monitieteisessä ilmapiirissä.

Caroline Sumpterin tuore tutkimus The Victorian Press and the Fairy Tale tuo satututkimusdebattiin uusia kysymyksenasetteluja yhdistämällä mediahistorian, folkloristiikan ja kirjallisuudentutkimuksen näkökulmia. Suullisuuden myytti autenttisuuden merkitsijänä perustuu 1800-luvun ajatteluun, jota Sumpter omalla tutkimuksellaan on purkamassa. Kirja kyseenalaistaa 1800-luvun valitukset siitä, miten "lehdistö tappoi kansansadut". Keskustelu kansansatujen kuolemasta juontaa juurensa vuosisatojen taakse. Lehdistöstä tuli kansansatujen kuoleman symboli, koska se kytkeytyi vahvasti 


\section{KIRSTI SALMI-NiKLANDER}

moniin muihin suullista perinnettä uhkaaviin modernisaatioilmiöihin kuten kaupungistumiseen, teollistumiseen ja yleiseen oppivelvollisuuteen.

Fairy tale -termin määrittely oli 1800-luvulla englannin kielessä monimutkainen ja poikkesi suomalaisista ihmesadun määrittelystä. Joskus nämä sadut määriteltiin kirjaimellisesti "keijukaistarinoiksi", vaikka monissa perinteisissä ihmesaduissa näitä yliluonnollisia hahmoja ei lainkaan esiinny. Viktoriaanisen ajan folkloristit erottivat kansansadun ja taidesadun vahvasti toisistaan, vaikka tosiasiassa näiden kerronnan muotojen välinen raja oli häilyvä.

\section{UUSIA JA VANHOJA JULKAISUMUOTOJA}

Sumpter kohdistaa analyysinsa erityisesti satujen lukemiseen aktiivisena ja vuorovaikutteisena toimintana. Hän tarkastelee sitä, miten viktoriaaninen lehdistö eri muodoissaan hyödynsi kansansatuja, "loi ne uudelleen" ja samalla kutsui niille uusia lukijayleisöjä. Tutkimus kohdistuu myös satujen vastaanottoon, jota Sumpter tutkii lehtien lukijakirjeiden ja muiden yksityisten arkistoaineistojen avulla. Kirjan neljä alalukua keskittyvät kukin erityiseen lehdistön muotoon: lastenlehtiin, aikuisille suunnattuihin huokeisiin julkaisuihin (engl. shilling montblies, penny weeklies), työväenlehdistöön ja vuosisadan vaihteen älymystöpiireissä toimitettuihin vaihtoehtojulkaisuihin (engl. Little Magazines). Yhteiseksi teemaksi näiden kaikkien julkaisumuotojen piirissä nousee lapsuuden symbolinen merkitys, joka saa erilaisia ideologisia painotuksia eri kirjoittaja- ja lukijayhteisöissä.

Laajalle yleisölle suunnattu huokeahintainen lehdistö laajeni Englannissa 1700-1800-luvun vaihteessa ja syrjäytti perinteisen arkkikirjallisuuden (engl. chapbooks). Kysymyksessä oli eräänlainen hybridi julkaisumuoto, jossa arkkikirjallisuus "sarjoittui" ja alkoi muistuttaa enemmän sanoma- tai aikakauslehdistöä. Sumpter (s. 21) nostaa esille kuvauksen irlantilaisen Irish Penny Magazinen lukutilanteesta 1830-luvun alusta: ryhmä samassa oluttuvassa istuvia talonpoikia osti kukin vuorollaan lehden, jota sitten luettiin ääneen oluttuvassa. Eräs talonpojista kehui, miten hän oli onnistunut saamaan lehteen itse sepittämänsä tarinan, jota oli väittänyt toimittajille "vanhaksi kansansaduksi”. Kertomus on viehättävä esimerkki fiktion ja folkloren, kirjallisen ja suullisen tradition vuorovaikutuksesta. Vastaavia huomioita on tehnyt Satu Apo (2007) 1800-luvun suomalaisten aineistojen pohjalta.

Lasten- ja nuortenlehdistö lisääntyi Englannissa vahvasti 1860-luvulla. Sumpter vertailee erityisesti kahta lastenlehteä: Aunt Judy's Magażine oli suunnattu nuorelle keskiluokkaiselle lukijayleisölle, Chatterbox taas työväenluokan lapsille. Suullinen kerronta oli vahva teema molemmissa lehdissä, mutta sen erilaiset merkitykset korostuvat niiden kansikuvissa 1880-luvulla: Chatterboxin kannessa vanha nainen, eräänlainen "Hanhiemo" kertoo tarinoita meluaville lapsille; Aunt Judy's Magazinen kannessa taas keski-ikäinen nainen lukee ääneen lehden numeroa lapsille. Sumpter analysoi myös Aunt Judy's Magazinen lukijakirjeitä ja sen toimittajien kirjoittamia käsinkirjoitettuja perhelehtiä, joissa lehdistön lajityyppejä parodioitiin. "Kotikirjoittaminen" ja painettujen julkaisujen avustaminen tapahtuivat joillakin kirjoittajilla jopa osittain samanai- 
kaisesti, joten käsinkirjoitetut lehdet toimivat "todellisen" julkaisemisen harjoitteluna ja kommentointina vastaavasti kuin suomalaisissa aineistoissa.

Myös aikuiselle, keskiluokkaiselle lukijayleisölle suunnattu lehdistö (engl. shilling monthlies) lisääntyi 1860-luvulla. Eräs näistä oli Macmillan's jossa julkaistiin sarjaromaanina Charles Kingsleyn The Water-Babies (1862-1863, suom. Vellamon lapset 1931). Kingsleyn erikoinen teos käsittelee sadun muodossa yhteiskunnallisia ongelmia ja evoluutiokysymystä, ja se herätti heti ilmestyttyään kiivasta keskustelua. Lehdissä julkaistiin myös muita kertomuksia, joissa käytettiin kansansatujen kuvakieltä, mutta korvattiin ihmeet realistisilla juonikäänteillä. Näiden uudelleen kirjoitettujen satujen avulla kommentoitiin muun muassa naiskysymystä.

\section{OlivatKo KeIJUT SOSIALISTEJA?}

Omalta kannaltani Sumpterin kirjan kiinnostavin luku liittyy satuaiheiden käsittelyyn brittiläisessä työväenlehdistössä 1890-luvulla. Sumpterin esille nostamia kysymyksiä olisi jännittävää tutkia myös suomalaisissa aineistoissa. "Sosialistikeijujen" tarina jäi lyhyeksi, mutta se tuo esille monia jännitteitä ja syrjään jääneitä ideoita varhaisen työväenliikkeen ajattelussa.

Satuja julkaistiin erityisesti työväenlehtien lapsille suunnatuissa liitteissä. Niiden merkittävä toimittaja oli Robert Blatchford, jonka ajatukset tulivat tutuiksi myös suomalaisen työväenliikkeen jäsenille Iloinen Englanti -teoksen pohjalta (suom. 1903). Satuaiheiden käsittely liittyi Labour Church -liikkeeseen, joka ajoi uskonnon vapautta yhdistettynä sosialistisiin aatteisiin. Liikkeen aloitteesta perustettiin slummien lapsille "Tuhkimokerhoja" (engl. Cinderella Club), joissa lapset saivat ruokaa ja hyödyllistä huvia. Satuaiheita hyödynnettiin työväenlehdistön pilapiirroksissa, mutta niissä julkaistiin myös sosialismin hengessä uudelleen kirjoitettuja satuja, joista tunnetuimpia oli Keir Hardien Jack Clearbead (1895). Työväenlehtien lukijapalstoilla sadut saivat myös interaktiivisia muotoja, kun lukijat kommentoivat ja kirjoittivat niitä uudelleen.

Suomalaisen työväenliikkeen retoriikkaan omaksuttiin vaikutteita sekä suomalaisesta suullisesta perinteestä että kansainvälisestä keskustelusta. Omiin tutkimuksiini liittyen minulla on myös yksi "keijuhavainto" varsin yllättävästä lähteestä. Karkkilalaisen 22-vuotiaan metallisorvarin Lennart Berghällin runo "Kurjalassa" julkaistiin käsinkirjoitetussa Valistaja-lehdessä maaliskuussa 1917. Se huipentuu visioon työläisten ja sosialismin voitosta: "Katso huomenrusko koittaa / uusi päivä sarastaa / keijut voitonvirttä soittaa / rauhanhymni kajahtaa." Tutkiessani Lennart Berghällin Helsingin-vaiheita (hän muutti Karkkilasta Helsinkiin jo 1915) ja nuorta työläisälymystöä ennen sisällissotaa tämä yksityiskohta on saanut mahdollisen selityksensä. Lennart tunsi mitä ilmeisimmin työläiskirjailija Kasperi Tantun (1886-1918), joka oli itse opiskellut englantia ja suomensi joitakin Percy Bysshe Shelleyn vallankumouksellisia runoja. Tanttu välitti kirjallista yleissivistystään työläisnuorille sekä luennoilla että yksityisessä kirjallisessa kerhossa. Shelleyn vallankumouksellinen "keijurunoelma" Queen Mab (1813) kaikuu mahdollisesti Lennart Berghällin runon taustavaikuttajana. 


\section{KIRSTI SALMI-NiKLANDER}

Työväenlehdistöstä Sumpter siirtyy hyvin erilaiseen julkaisu- ja lukijayhteisöön, vuosisadan vaihteen älymystöpiirien dekadenssikulttuuriin ja homoseksuaalien alakulttuuriin. Monilla tämän piirin kirjoittajista oli kuitenkin yhteyksiä sosialisteihin. Tunnetuin heistä on Oscar Wilde, jonka satuja (muun muassa Onnellinen prinssi) suomennettiin jo 1907. Vähemmän tunnettu mutta hyvin kiinnostava satukirjailija oli Lawrence Housman, Sumpterin märritelmän mukaan "kirjoittaja, kuvittaja ja kirjansuunnittelija, sosialisti, feministi ja homoseksuaali". Satuja julkaistiin pienilevikkisissä vaihtoehtojulkaisuissa, jotka levisivät suljetuissa älymystöpiireissä. Homoseksuaalien alakulttuurissa satuja käytettiin koodikielenä, jossa kukka- ja kuusymboliikka olivat tärkeitä vaihtoehtoisen seksuaalisuuden ilmaisijoita.

\section{Englannista Suomeen, Wildesta Päivärintaan}

Keijut ja lapset ovat Sumpterin osatutkimusten kokoavia teemoja, jotka saavat erilaisia rooleja ja symbolisia merkityksiä eri lukijayhteisöissä ja ideologisissa konteksteissa. 1800-luvun loppupuolen lasten- ja nuortenlehdissä lapsuus nähtiin mielikuvituksellisen aitouden tilana romantiikan hengessä. Lapsuus sai uusia merkityksiä evoluutiokeskustelussa. Siinä lapsen kehityksen katsottiin heijastavan kansallisen, kulttuurisen ja biologisen kehityksen varhaisvaiheita. Sosialistisessa keskustelussa, erityisesti niin kutsutun eettisen sosialismin piirissä, lapsi edusti menneisyyden aitoja ja turmeltumattomia sosiaalisia suhteita, utopistisessa sosialismissa taas unelmaa jälkikapitalistisesta kulttuuri-integraatiosta. Keijut toimivat sosialistisissa saduissa moraalisen opetuksen välittäjinä. Vuosisadan vaihteen dekadenssikulttuurissa ja homoseksuaalien alakulttuurissa lapset edustivat individualismia ja keijut puolestaan kiellettyjä, vaihtoehtoisia seksuaalisuuden muotoja. "Fairy" oli tuona aikana myös yleisesti käytetty naismaisen homoseksuaalin peitenimi.

Sumpterin kiinnostavien mutta välillä rönsyilevien osatutkimusten jälkeen loppuluku jää varsin suppeaksi. Myös tiettyä anglosaksista sisäänlämpiävyyttä on havaittavissa - tekijä olettaa lukijan itsestään selvästi tuntevan monia kirjailijoita ja tekstejä, jotka suomalaiselle lukijalle eivät välttämättä ole kovin tuttuja. Charles Kingsleyn Vellamon lapsia ja Oscar Wilden satuja tuntemattomalle voi Sumpterin kirjan lukeminen olla työlästä. On ymmärrettävää, että kirjoittaja on halunnut pysyä tiiviisti aiheessaan ja pitää kirjan sivumäärän kurissa, mutta ei-anglosaksisten lukijoiden kannalta olisi ollut hyvä selvittää kirjallisia ja historiallisia taustoja vähän tarkemmin.

Sitäkin yllättävämpi on viimeisen sivun pitkähkö Pietari Päivärinta -sitaatti, jonka käännös (teoksesta Elämäni, SKS 1877) on peräisin Satu Apon englanniksi ilmestyneestä tutkimuksesta. Kertojaminä (Päivärinta itse) muistelee nuoruuden kerjuukokemuksiinsa liittyvää tilannetta 1830-luvulta, jossa hän esitti sanomalehdestä ("pitkästä kirjasta, jossa mikään ei pääty") lukemansa tarinan suullisesti ja tätä esitystä kommentoitiin. Tämä loppusitaatti tuo hiukan yllätyksellisenäkin esille niitä uusia mahdollisuuksia, joita kansainväliset vertailevat perspektiivit voivat tuoda suullisen ja kirjallisen kulttuurin monitahoisen vuorovaikutuksen tutkimukseen. Tämä vaatii tosin työlästä perustutkimusta ja kääntämistä, mutta se voi viedä niin folkloristista kuin mediahistoriallistakin tutkimusta uusille urille. 
KEIJUJEN UUSI ELÄMÄ LEHTIEN PALSTOILLA

\section{KirjallisuUs}

APO, SATU 2007: The Relationship between Oral and Literary Tradition as a Challenge in Fairy-Tale Research: The Case of Finnish Folktales. - Marvels \& Tales 21(1).

BOTTIGHEIMER, RUTH B. 2002: Fairy Godfather: Straparola, Venice, and the Fairy Tale Tradition. Philadelphia: University of Pennsylvania Press.

BOTTIGHEIMER, RUTH B. 2009: Fairy Tales. A New History. New York: SUNY Press.

SALMI-NIKLANDER, KIRSTI 2009: Kirjallistuminen ja kansanomainen kirjakulttuuri keskusteluun. - Elore (16)1. [online] < http://www.elore.fi/arkisto/1_09/ ajank_salmi-niklander_01_09.pdf >

Kirsti Salmi-Niklander on folkloristiikan dosentti Helsingin yliopistossa. 